\title{
The Role of Financial Behavior, Financial Attitude, Financial Strain, and Risk Tolerance in Explaining Financial Satisfaction
}

\author{
Stella Winarta ${ }^{1}$, Ary Satria Pamungkas ${ }^{1}$ \\ ${ }^{1}$ Faculty of Economics and Business, Universitas Tarumanagara, Jakarta, Indonesia \\ *Corresponding author. Email: aryp@fe.untar.ac.id
}

\begin{abstract}
The purpose of this study was to determine the role of Financial Behavior, Financial Attitude, Financial Strain, and Risk Tolerance in explaining Financial Satisfaction among female workers. The sample used in this study are women who work in Jakarta and have a minimum education level of bachelor degree except in the Construction, Transportation and Warehousing, and Real Estate sectors. The sample in this study was 192 respondents selected by using the convenience sampling method. Data analysis techniques used Structural Equation Modelling (SEM). The result of this study indicated that Financial Behavior and Risk Tolerance have an influence on Financial Satisfaction, while Financial Attitude and Financial Strain have no effect on Financial Satisfaction.
\end{abstract}

Keywords: Financial Behavior, financial attitude, financial strain, risk tolerance, financial satisfaction

\section{INTRODUCTION}

Each individual has his or her own goals to achieve, which basically these goals are different from one individual to another. Although they are different, all of these goals lead to the same point, that is to obtain welfare and prosperity in life. This welfare can be included in various things such as health, education, and the most common problem is financial well-being.

Financial well-being is a perception of financial freedom that a person has to set and maintain the standard of living that the person wants [1]. The welfare and prosperity in financial felt by each individual is relative. There are individuals who have high income every month, but still feel that they are poor and not satisfied with their financial conditions. There are also individuals who have low income, but feel that all the necessities of life are met and have a happier life.

Financial management is one of the things needed to achieve the welfare and prosperity in life. Mistakes and failures in financial management by an individual can have a big impact on the level of welfare obtained by the individual [2]. Failure in financial management can cause conflicts between individuals in the family as well as with other people. This conflict can occur because of dissatisfaction with someone's financial status.

Financial satisfaction refers to a subjective evaluation of the extent to which a person's financial resources are adequate or inadequate, and satisfactory or unsatisfactory [3]. Financial satisfaction is a perception that a person has about his or her financial condition, whether the individual is satisfied or not with such financial condition.

The higher the income received by a person is, the more consumption is made to meet all his / her needs so that in the end that person will feel satisfied with the financial condition. To achieve this financial satisfaction, an individual works in various sectors to generate income to meet his or her daily needs.

The research results obtained by the McKinsey Global Institute in 2018 stated that Indonesia's annual GDP in 2025 could increase by US\$ 135 billion, if Indonesia could accelerate gender equality. However, in reality, gender inequality is still widely felt by female workers in Indonesia not only in work participation but also in terms of income or wages received.

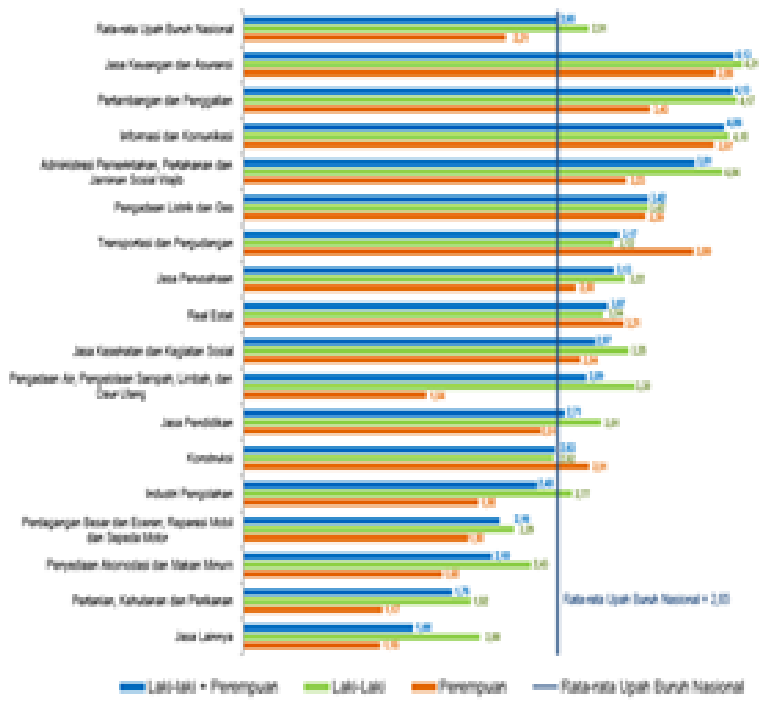

Figure 1 The average monthly wages of workers by jobs and gender 
Figure 1 shows the condition of the workforce in Indonesia as of February 2018, which shows the difference in wages received by male and female workers. Most of the wages earned by females have a smaller percentage than those earned by males, although there are several sectors of work in which females can earn higher wages such as construction sector, transportation and warehousing sector, and real estate sector. The existence of gender inequality in terms of wages is indicated to have an adverse impact on working females to achieve high financial satisfaction.

One of the things that can be considered to determine a person's financial satisfaction is how the person behaves in managing his / her personal finances. Financial Behavior is the level of an individual or household's ability to manage financial resources including the planning to earn money, managing and controlling finances, and practices related to cash and credit management [4]. Financial Behavior is closely related to spending, borrowing, and saving. The wrong Behavior in managing finance can cause serious social problems that can last for a long time [5].

Financial attitude has a very important role in determining whether someone is satisfied or not with their finances. Financial attitude is a psychological tendency displayed by someone regarding the agreement or disagreement in evaluating financial management [2]. A person's financial attitude can be influenced by how the person sees and assesses financial actions that are considered correct from his / her own or other people's perspectives, and is also influenced by his / her financial experience [6].

The increasing demand for the needs and the cost of living, which is getting bigger from year to year, makes a person have financial strain which will have a negative impact for someone's life such as the emergence of conflicts within the family and with certain people so that in the end it will cause dissatisfied feeling with his or her finance. In the financial planning process, risk management is one of the most important things to achieve financial satisfaction. Evaluating financial risk is the main thing that an individual needs to do in order to achieve a large rate of return below the limits of financial ability and the limits of risk that the individual can tolerate [7]. Risk tolerance is one of the problems which is the basis for making financial decision related to income, expenditure, or choices in choosing the available investment products [8].

\section{LITERATURE REVIEW}

\subsection{Financial Behavior}

According to [9], "financial Behavior can be defined as any human Behavior that is relevant to money management." [10] explained that "financial Behavior refers the handling of one's income and financial situation, i.e. the orientation of the individual toward everyday financial matters. Financial Behavior means the ability of individuals to manage their finances to be successful in life." The results of research conducted by [11] show that financial Behavior has positive effect on financial satisfaction. This shows that someone who has good financial Behavior, will have a higher level of financial satisfaction. Thus, the first hypothesis can be developed as follow:

$\mathrm{H}_{1}$ : Financial Behavior has a positive effect on financial satisfaction.

\subsection{Financial Attitude}

Financial attitude is defined as the application of financial principles to create and maintain value through decision making and proper resource management [12]. Financial attitude is a state of mind or psychological tendency in form of a person's opinion and judgment which is expressed when evaluating financial management practices. [13] stated that financial attitude has a positive effect on financial satisfaction. Financial satisfaction will increase, if someone has a good financial attitude. Thus, the second hypothesis can be developed as follow:

$\mathrm{H}_{2}$ : Financial attitude has a positive effect on financial satisfaction.

\subsection{Financial Strain}

[14] stated that "financial strain is a measure that gives psychological meaning to the experience of economic difficulties." Financial strain is a measurement used to measure a situation that arises from the existence of several forms of financial difficulties that can cause stress and have an impact on a person's mental health. [4] concluded that someone who has a lower level of financial strain, will ultimately increase financial satisfaction. Therefore, the third hypothesis can be developed as follow:

$\mathrm{H}_{3}$ : Financial strain has a negative effect on financial satisfaction.

\subsection{Risk Tolerance}

According to [15], "risk tolerance can be defined as the maximum amount of uncertainty that someone is willing to accept when making a financial decision, that reaches into almost every part of economic and social life." Risk tolerance is the level of uncertainty that a person can accept for his or her financial decisions. Research conducted by [11] found that risk tolerance has a negative effect on financial satisfaction. Someone who has a high level of risk tolerance, tends to have high financial expectations and standard of living so that he or she has a low level of financial satisfaction. Thus, the fourth hypothesis can be developed as follow:

$\mathrm{H}_{4}$ : Risk tolerance has a negative effect on financial satisfaction.

\subsection{Financial Satisfaction}

[16] explained that "financial satisfaction is considered as a subjective evaluation of financial status that is closely related to subjective well-being." Financial satisfaction can be interpreted as a perception possessed by a person that can describe the level of welfare in general regarding his or her 
current financial condition as seen by the existence of a healthy, happy, and free from financial worries.

\section{RESEARCH METHODOLOGY}

\subsection{Data Collection}

This study used the descriptive research design by using quantitative approach. The population used in this study are all females who were working in Jakarta and had a minimum education level of bachelor degree except in the Construction, Transportation and Warehousing, and Real Estate sectors. The sampling technique used in this study was convenience sampling, in which the sampling was carried out because of the element of ease in obtaining the required data. The number of samples used in this study was 192 respondents. The type of data used in this research is primary data which was carried-out through questionnaires which are distributed manually, and online by using Google Form. The filling of questionnaire was carried out by respondents by providing an assessment of the available statements whether strongly disagree, disagree, neutral, agree, and strongly agree, using a Likert scale with a score ranging from 1 to 5 .

\subsection{Independent Variables}

Financial Behavior was measured by using 5 items, as adapted from [11]: (1) "I set money aside for savings", (2) "I have a weekly or monthly budget that I follow", (3) "I don't spend more money than I have", (4) "I have a plan to reach my financial goals", and (5) "I don't have financial troubles, because I have enough money".

Financial attitude was measured by using 5 items, as adapted from [17] and [13]: (1) "Money is not to be spent", (2) "Each individual must take responsibility for his or her own financial well-being", (3) "Saving is important", (4) "Written budget is essential for successful financial management", and (5) "Financial planning for retirement is necessary to ensure the safety of a person during old age". Financial strain was measured by using 4 items, as adapted from [4] and [18]: (1) "Borrowing money from friends", (2) "Not aware how money was spent", (3) "Spending more than income gained", and (4) "Having too much debt right now".

Risk tolerance was measured by using 4 items, as adapted from [11]: (1) "In terms of investing, safety is more important than returns", (2) "I feel more comfortable when putting my money in a bank account than in stock market", (3) "When I think of the word "risk", the term "loss" comes to mind immediately", and (4) "Making money in stocks and bonds is based on luck".

\subsection{Dependent Variable}

Financial satisfaction was measured by using 5 items, as adapted from [19]: (1) "I am satisfied with my current financial situation", (2) "I can do a lot to improve my current financial situation", (3) "I rarely run short of money", (4) "If I had a major loss of income, I could manage for a period of time", and (5) "I feel that my income can cover my living cost".

Data analysis technique used the Structural Equation Modelling (SEM). In this study, the model-fit test was carried-out in two stages, that is outer model and inner model.

\section{RESULTS AND DISCUSSIONS}

Table 1 Validity and Reliability Test Results

\begin{tabular}{|c|c|c|c|}
\hline Variable & AVE & $\begin{array}{c}\text { Cronbach's } \\
\text { Alpha }\end{array}$ & $\begin{array}{c}\text { Composite } \\
\text { Reliability }\end{array}$ \\
\hline Financial Attitude & 0.642 & 0.859 & 0.899 \\
\hline Financial Behavior & 0.529 & 0.782 & 0.849 \\
\hline Financial Satisfaction & 0.520 & 0.762 & 0.841 \\
\hline Financial Strain & 0.617 & 0.817 & 0.864 \\
\hline Risk Tolerance & 0.505 & 0.696 & 0.801 \\
\hline
\end{tabular}

In Table 1, all variables have the Average Variance Extracted (AVE) value more than 0.5, and also all variables have Cronbach's Alpha and Composite Reliability more than 0.6. So, it can be concluded that all variables in this study have met the requirements for validity and reliability. The coefficient of determination $\left(\mathrm{R}^{2}\right)$ of the financial satisfaction variable is 0.442 or $44.2 \%$. This means that $44.2 \%$ of variation in the financial satisfaction variable can be explained by the variables of financial Behavior, financial attitude, financial strain, and risk tolerance. Meanwhile, the goodness-of-fit generated in this study is 0.4987 . Therefore, it can be concluded that the suitability of the model generated in this study is large.

Table 2 The Result of Bootstrapping Test

\begin{tabular}{|l|c|c|c|}
\hline \multicolumn{1}{|c|}{ Variable } & $\begin{array}{c}\text { Path } \\
\text { Coefficient }\end{array}$ & $\begin{array}{c}\text { t- } \\
\text { statistics }\end{array}$ & $\begin{array}{c}\text { p- } \\
\text { values }\end{array}$ \\
\hline $\begin{array}{l}\text { Financial Attitude } \rightarrow \\
\text { Financial Satisfaction }\end{array}$ & -0.068 & 0.924 & 0.356 \\
\hline $\begin{array}{l}\text { Financial Behavior } \rightarrow \\
\text { Financial Satisfaction }\end{array}$ & 0.613 & 8.622 & 0.000 \\
\hline $\begin{array}{l}\text { Financial Strain } \rightarrow \\
\text { Financial Satisfaction }\end{array}$ & -0.011 & 0.137 & 0.891 \\
\hline $\begin{array}{l}\text { Risk Tolerance } \rightarrow \\
\text { Financial Satisfaction }\end{array}$ & -0.202 & 3.050 & 0.002 \\
\hline
\end{tabular}

The test of hypothesis 1 revealed that financial Behavior has a positive effect on financial satisfaction of female workers (path coefficient $=0.613$; t-statistics $=8.622$ (greater than $1.96) ; \mathrm{p}$-values $=0.000$ (less than 0.05)). Female workers who have good financial Behavior, will have high financial satisfaction. A good financial Behavior will encourage a person to control his or her finance through actions and financial decisions. The result of this study is in accordance 
with the result of previous studies conducted by [4] [11] [13].

The test of hypothesis 2 revealed that there is no effect of financial attitude on financial satisfaction among female workers (path coefficient $=-0.068$; t-statistics $=0.924$ (less than 1.96); p-values $=0.356$ (greater than 0.05)). Female workers who have a good financial attitude cannot guarantee a stable financial condition, and eventually the financial satisfaction is not fulfilled. The result of this study is in accordance with that of previous study conducted by [6], which shows that financial attitude does not affect financial satisfaction.

The test of hypothesis 3 revealed that there is no effect of financial strain on financial satisfaction among female workers (path coefficient $=-0.011$; t-statistics $=0.137$ (less than 1.96); $\mathrm{p}$-values $=0.891$ (greater than 0.05)). In this study, female workers as respondents stated that they have no financial pressure in their lives. However, some female workers as respondents still have doubts about their financial satisfaction, so it causes financial strain which cannot affect financial satisfaction. The result of this study is different from the result of previous studies conducted by [4] and [18].

The test of hypothesis 4 revealed that risk tolerance has a negative effect on financial satisfaction among female workers (path coefficient $=-0.202 ; \mathrm{t}$-statistics $=3.050$ (higher than 1.96); p-values $=0.002$ (less than 0.05)) Someone who has a high level of risk tolerance, will cause a decrease in financial satisfaction.

Female workers who have a low level of risk tolerance, tend to have a low standard of living, so they have high financial satisfaction. The result of this study is in accordance with that of previous study conducted by [11].

\section{CONCLUSIONS, LIMITATION, AND SUGGESTIONS}

The results of this study show that financial Behavior has a positive effect on financial satisfaction, and risk tolerance has a negative effect on financial satisfaction. Meanwhile, financial attitude and financial strain have no effect on financial satisfaction. This study has a limitation, which is only using female workers as respondents, so the results of this study can only be used to explain the financial satisfaction of female workers. Companies are advised to provide a pension fund program in order to provide certainty and increase the financial satisfaction of employees, especially for the females in the future. Companies are also advised to cooperate with academics and Indonesia Stock Exchange (IDX) through the program of "Yuk Nabung Saham" in order to provide the knowledge about investing in the capital market and to increase employee awareness about the importance of investing in stocks. The Jakarta Special Region Provincial Government are advised to create work-related programs in form of the socialization and training related to personal financial management to increase the financial satisfaction of the community, especially the females who are working in Jakarta.

\section{REFERENCES}

[1] Bruggen, E. C., Hogreve, J., Holmlund, M., Kabadayi, S., Lofgren, M., Financial well-being: A conceptualization and research agenda, Journal of Business Research, vol. 79, 2017, pp. 228-237. DOI: https://doi.org/10.1016/j.jbusres.2017.03.013

[2] Parrotta, J. L., Johnson, P. J., The impact of financial attitudes and knowledge on financial management and satisfaction of recently married individuals, Journal of Financial Counseling and Planning, vol. 9(2), 1998, pp. 59-74.

[3] Hira, T. K., Mugenda, O. M., Predictors of financial satisfaction: differences between retirees and nonretirees, Journal of Financial Counselling and Planning, vol. 9(2), 1998, pp. 75-84.

[4] Falahati, L., Sabri, M. F., Paim, L. H. J., Assessment a model of financial satisfaction predictors: examining the mediate effect of financial Behavior and financial strain, World Applied Sciences Journal, vol. 20(2), 2012, pp. 190-197. DOI: 10.5829/idosi.wasj.2012.20.02.1832

[5] Perry, V. G., Morris, M. D., Who is in control? The role of self-perception, knowledge, and income in explaining consumer financial behavior, Journal of Consumer Affairs, vol. 39(2), 2005, pp. 299-313. https://doi.org/10.1111/j.1745-6606.2005.00016.x

[6] Yap, R. J. C., Komalasari, F., Hadiansah, I., The effect of financial literacy and attitude on financial management behavior and satisfaction, International Journal of Administrative Science \& Organization, vol. 23(3), 2016, pp. 140-146. DOI:10.20476/jbb. v23i3.9175

[7] Jeong, W. Y., Hanna, S. D., Risk tolerance and financial satisfaction, International Journal of Human Ecology, vol. 5(1), 2004, pp. 35-43.

[8] Grable, J., Lytton, R. H., Financial risk tolerance revisited: the development of a risk assessment instrument, Financial Services Review, vol. 8, 1999, pp. 163-181. https://doi.org/10.1016/S10570810(99)00041-4

[9] Xiao, J. J., Applying behavior theories to financial behavior, Handbook of Consumer Finance Research, Springer, 2008, pp. 69-81. DOI: 10.1007/978-0-38775734-6_5

[10] Saurabh, K., Nandan, T., Role of financial risk attitude and financial behavior as mediators in financial satisfaction: empirical evidence from India, South 
Asian Journal of Business Studies, vol. 7(2), 2018, pp. 207-224. DOI: 10.1108/SAJBS-07-2017-0088

[11] Joo, S. H., Grable, J. E., An exploratory framework of the determinants of financial satisfaction, Journal of Family and Economic Issues, vol. 25(1), 2004, pp. 2550. DOI: 10.1023/B:JEEI.0000016722.37994.9f

[12] Rajna, A., Ezat, W. P. S., Junid, S. A., Moshiri, H., Financial management attitude and practice among the medical practitioners in public and private medical service in Malaysia, International Journal of Business and Management, vol. 6(8), 2011, pp. 105-113. DOI: 10.5539/ijbm.v6n8p105

[13] Arifin, A. Z., Influence of financial attitude, financial behavior, financial capability on financial satisfaction, Advance in Social Science, Education and Humanities Research, vol. 186, 2018, pp. 100-103. DOI: $10.2991 /$ insyma-18.2018.25

[14] Gutman, L. M., McLoyd, V. C., Tokoyawa, T., Financial strain, neighborhood stress, parenting behaviors, and adolescent adjustment in urban African American families, Journal of Research on Adolescence, vol. 15(4), 2005, pp. 425-449. DOI: 10.1111/j.1532-7795.2005.00106.x

[15] Grable, J. E., Financial risk tolerance and additional factors that affect risk taking in everyday money matters, Journal of Business and Psychology, vol. 14(4), 2000, pp. 625-630. DOI:

10.1023/A:1022994314982

[16] Xiao, J. J., Chen, C., Chen, F., Consumer Financial Capability and Financial Satisfaction, Social Indicators Research, vol. 118(1), 2014, pp. 415-432. DOI: 10.1007/s11205-013-0414-8

[17] Kirbis, I. S., Vehovec, M., Galic, Z., Relationship between financial satisfaction and financial literacy: exploring gender differences, Journal for General Social Issues, vol. 26(2), 2017, pp. 165-185. DOI: 10.5559/di.26.2.02

[18] Woodyard, A. S., Robb, C. A., Consideration of financial satisfaction: what consumers know, feel and do from a financial perspective, Journal of Financial Therapy, vol. 7(2), 2016, pp. 41-61. DOI: 10.4148/1944-9771.1102

[19] Ali, A., Rahman, M. S. A., Bakar, A., Financial satisfaction and the influence of financial literacy in Malaysia, Social Indicators Research, vol. 120(1), 2015, pp. 137-156. DOI: 10.1007/s11205-014-0583-0 